\title{
Protein Sprouty Homolog 4
}

National Cancer Institute

\section{Source}

National Cancer Institute. Protein Sprouty Homolog 4. NCI Thesaurus. Code C105084.

Protein sprouty homolog 4 (299 aa, $\sim 33 \mathrm{kDa}$ ) is encoded by the human SPRY4 gene. This protein plays a role in the inhibition of receptor-mediated signaling pathways. 